\title{
Immunogenic Study for CX3CR1 Molecule in Rheumatoid Arthritis Patients
}

\author{
MOHAMED F. ELSHAL, M.D.*; SALAMA M. EL SHINNAWY, M.D.** and \\ AHMED S. HASABELNABY, M.Sc.*** \\ The Department of Molecular Biology*, Genetic Engineering and Biotechnology Research Institute, University of Sadat City, \\ Sadar City, Egypt, The Departments of Microbiology \& Immunology** and Clinical Pathology***, GOTHI, Shebein El-Kom \\ Teaching Hospital, Egypt
}

\begin{abstract}
Background: CX3C Chemokine Receptor 1 (CX3CR1) is a chemokine receptor which interact with the proinflammatory chemokine fractalkine and participates in the pathology of inflammatory arthritis.

Aim of Study: This study aimed to evaluate the variations of CX3CR1 in rheumatoid arthritis.

Subjects and Methods: A case-control study involved 50 male and female Rheumatoid Arthritis (RA) cases and 25 healthy controls. Disease activity, Anti-Cyclic Citrullinated Peptide (Anti-CCP), Erythrocyte Sedimentation Rates (ESR), Rheumatoid Factor (RF), C-Reactive Protein (CRP) were evaluated as well as assessment of the variations in CX3CR1 by Flowcytometric studies or Polymerases Chain Reactions (PCR).

Results: A significant link was detected between RA and CX3CR1 $(p=0.0001)$ with three types of genotyping detected using high resolution melting PCR as; AA constituted the highest percentage in cases (28\%) compared to controls (20\%), AG was detected in 21 cases (42\%) and not detected in controls $(0 \%)$ and GG was detected in 15 cases $(30 \%)$ versus 20 controls $(80 \%)$. Also, cases showed significant increase in median flow than the control (4.8 vs. 1.26 respectively) $(p=.0001)$. A significant positive association was detected between the flowcytometry and C-reactive protein, erythrocyte sedimentation rates rheumatoid factor, Anti-CCP and the number of affected joints.
\end{abstract}

Conclusion: CX3CR1 is a valuable biomarker of RA activity with a significant role in the local joint inflammatory reaction sparing other body parts.

Key Words: Activity - CX3CR1 - Rheumatoid - Severity.

\section{Introduction}

RHEUMATOID Arthritis (RA) is a chronic autoimmune disorder that trigger an inflammatory

Correspondence to: Dr. Mohamed F. Elshal, The Department of Molecular Biology, Genetic Engineering and Biotechnology Research Institute, University of Sadat City, Sadar City, Egypt reaction in the musculoskeletal system causing a chronic severe pain, joints destruction and deformity [1]. The migration of immune cells as CD4+ T cells to lymphoid or rheumatoid synovial tissue play the major role in RA pathogenesis and is triggered by several factors as the chemokine receptors expression profile [2].

One of the member of chemotactic cytokines is the chemokines which includes four subfamilies (C, CC, CXC, and CX3C) that have been reported to be responsible for stimulation and activation of immune cells. The chemokines form a solid phase gradients when immobilized on proteoglycans [3].

Chemokine receptors belong to the seven transmembrane $\mathrm{G}$ protein-coupled receptor family which upon binding to the cognate chemokine, it activates integrin-dependent cellular adhesion. CX3C chemokine receptor 1 (CX3CR1) is a chemokine receptor which binds to the proinflammatory chemokine (fractalkine (FKN) or CX3CL1 and has a major role in the inflammatory arthritis response [4].

Chemokine receptors is responsible for lymphocytes trafficking, modulation of the gene expression on target cells as well as cellular proliferation and apoptosis [5]. Apoptosis resistance or

\begin{tabular}{ll}
\hline Abbreviations \\
ESR $\quad$ : Erythrocyte Sedimentation Rates. \\
CRP $\quad$ : C-Reactive Protein. \\
RF $\quad$ : Rheumatoid Factor. \\
Anti-CCP : Anti-Cyclic Citrullinated Peptide. \\
RA $\quad$ : Rheumatoid Arthritis. \\
DAS-28 & : Disease Activity Score-28. \\
CX3CR1 & : CX3C chemokine receptor 1. \\
PBS & : Phosphate Buffer Saline. \\
RPMI & : Roswell Park Memorial Institute.
\end{tabular}


longevity of CD4+ T cells has been linked to the extensive lymphocytic infiltration of synovial tissue which exacerbates the RA-induced inflammatory reaction [6]. The aim of this study was to study the variations of the inhibitory molecules (CX3CR1) in RA.

\section{Subjects and Methods}

A case-control study involved 50 male and female RA cases older than 18 years diagnosed according to the 1987 criteria of the American College of Rheumatology and 25 ages and sex matched healthy individuals as a control group gathered from the Rheumatology Outpatients' Clinic between July 2018 and May 2019. Approval of the Local Ethical Committee was granted before starting the study and each participant signed an informed written consent before joining the study. Patients with advanced hepatic disorder, malignancy, renal failure, infectious diseases or any other inflammatory disorders were excluded from the study.
The activity of RA was determined based on the clinical parameters and the level of the inflammatory markers, Erythrocyte Sedimentation Rates (ESR) and C-Reactive Protein (CRP). Detailed history was obtained from each patient who were then thoroughly clinically examined and finally tested for variations in CX3CR1 by the Flowcytometry or the Polymerases Chain Reactants (PCR).

\section{Genotyping of CX3CR1 (rs3732378) variants:}

The purified PCR products were evaluated in the MacroGen Company (South Korea) where the bi-directional sequencing was done by the ABI 3730XL DNA sequencer (Applied Biosystem, USA). Then the Chromas Lite 2.1 program (http:// technelysium.com.au/?page_id=13) was used for analysis of the resulting sequences followed by identification of the identity of the sequenced PCR products by Blast search against GenBank database of human (http://blast.ncbi.nlm.nih.gov/Blast.cgi) and lastly alignments, annotations and assembly by the Geneious 4.8 .4 software http://www. geneious.com/web/geneious/home. The primer sequences have shown in (Table 1).

Table (1): Forward and reverse primers sequence for primers used in qPCR.

\begin{tabular}{llcccc}
\hline Gene & Forward (F) and Reverse (R) & $\begin{array}{c}\text { Size } \\
(\mathrm{bp})\end{array}$ & Localization & $\begin{array}{c}\text { Accession } \\
\text { number }\end{array}$ & AA \\
\hline CX3CRI & $\begin{array}{l}\text { F: AAATCTGGCCCGTGCTCCGC } \\
\text { R: CGCCCACACAGGACAGCCAG }\end{array}$ & 400 & Exon2 & NM-001171172.1 & $\begin{array}{l}\text { C>T: Theronine } \\
\text { >Methionine }\end{array}$ \\
\hline
\end{tabular}

Real-time PCR with SYBR Green was utilized for measuring the expression of mRNAs of the target genes in the blood after amplifying the isolated DNA by gene specific primers and $2 \mathrm{X}$ Maxima SYBR Green/ROX qPCR Master Mix according to the instructions of the manufacturer (Thermo scientific, USA, \# K0221), with $\beta$-actin as an internal reference.

Aseptic withdrawal of $6 \mathrm{ml}$ of peripheral blood of all participants was done and samples were kept in heparinized tubes for the flowcytometry for CX3CR1. Sample layering was done on ficollhypaque in $15 \mathrm{ml}$ conical centrifuged tube at ratio one volume of ficoll to two volumes of blood, then the tubes were centrifuged for 30 minutes at 1800 rpm yielding the following layers bottom to top: Red blood cells, clear layer, opaque interface containing the lymphocytes and plasma layer. The upper layer was removed within $1.5 \mathrm{~cm}$ of the opaque interface. Pasteur pipette was used for collecting the lymphocytes via a careful transfer of the opaque interface into a sterile $15 \mathrm{ml}$ conical centrifuge tube then a sterile Phosphate Buffer
Saline (PBS) was used to wash the cells to be then spun at 2200rpm for 5 minutes, the PBS was aspirated leaving the cell pellet and immediately sterile Roswell Park Memorial Institute (RPMI) was added. Tubes were inverted to mix and were spun at $2200 \mathrm{rpm}$ for 5 minutes and cell pellet were resuspended in $6 \mathrm{ml}$ sterile RPMI media supplemented with $10 \%$ FBS \& Penicillin-streptomycin $(10,000$ $\mathrm{U} / \mathrm{ml}$ and $10,000 \mu \mathrm{g} / \mathrm{ml})$.

Then sample containing viable cells was subjected to a PBS washing two times then centrifugation at 2000rpm for 5 minutes to be followed by transferring the cells into tubes; the first tube contained $10 \mu \mathrm{l}$ of cell suspension with no Abs and was used as a control for the adjustment of the machine, obtaining the basic histogram that demonstrates the main cell population and adjustment of the auto-fluorescence region. The other tubes contained $6 \mu 1$ of Abs (CX3CR1 PE-A, CD4 APCA, CD3 FITC-A) added and mixed with the sample to be subjected for dark incubated for 30 minutes then washing by adding $500 \mu$ of $5 \%$ PBS and centrifugation at $2000 \mathrm{rpm}$ for 5 minutes and finally 
a re-suspension of the packed cells in $300 \mu 1$ PBS to be used for the flowcytometric studies.

\section{Statistical analysis:}

It was performed using SPSS statistics software version 23. Quantitative data were described by mean, range and standard deviation. Qualitative data were expressed by numbers and percent. The following tests were used: Chi-square test to compare two groups according to the demographic characteristics. Monte Carlo test to compare two groups regarding the relationship between RA and CX3CR1, and RA and Flowcytometry, KruskalWallis test to assess the relationship between CX3CR1 among patients diagnosed with RA with number of joint affected. $p$-value $<0.05$ was considered significant.

\section{Results}

The demographic characteristics were insignificantly different between the two groups, as regarding the sex, females constituted the majority (90\%) of cases and $(92 \%)$ of controls $\left(\chi^{2}=0.079 \& p=\right.$ $0.779)$. There were no statistically significant differences regarding the age as the mean age of cases was ( $38.7 \pm 13.4$ years) and (38.9 \pm 14.11 years) in controls.

Table (2): Distribution of study cases according to RA investigations \& number of joint affected.

\begin{tabular}{lll}
\hline & Mean \pm SD & $\begin{array}{l}\text { (Minimum- } \\
\text { maximum) }\end{array}$ \\
\hline ESR $(\mathrm{mm} / \mathrm{hr})$ & $19.02 \pm 9.14$ & $(8-46)$ \\
$\mathrm{CRP}(\mathrm{mg} / \mathrm{dl})$ & $3.86 \pm 1.27$ & $(1.9-8.3)$ \\
$\mathrm{RF}(\mathrm{IU} / \mathrm{ml})$ & $10.9 \pm 6.225$ & $(2.14-33.7)$ \\
AntiCCP $(\mathrm{U} / \mathrm{mL})$ & $38.3 \pm 65.5$ & $(2.3-314)$ \\
Number of joints affected & $3 \pm 1.8$ & $(2-8)$
\end{tabular}

\begin{tabular}{ll}
\hline RA & : Rheumatoid Arthritis. \\
ESR & : Erythrocyte Sedimentation Rates. \\
$\mathrm{CRP}$ & : C-Reactive Protein. \\
$\mathrm{RF}$ & : Rheumatoid Factor. \\
Anticcp & : Anti-cyclic citrullinated peptide. \\
$\mathrm{CX} 3 \mathrm{CR} 1:$ & CX3C chemokine receptor 1. \\
$\mathrm{SD}$ & $:$ Standard Deviation. \\
$\mathrm{Mg} / \mathrm{dl}$ & $:$ Milligram/deciliter. \\
$\mathrm{U} / \mathrm{ml}$ & $:$ Unit/milliter. \\
$\mathrm{IU} / \mathrm{ml}$ & $:$ International unit/milliter. \\
$\mathrm{Hr}$ & $:$ Hour.
\end{tabular}

Table (2) shows descriptive analysis of the participants according to RA investigations \& number of joint affected. The mean value of ESR was $19.02 \pm 9.14 \mathrm{~mm} / \mathrm{hr}$, CRP was $3.86 \pm 1.27 \mathrm{mg} / \mathrm{dl}$, RF was $10.9 \pm 6.225 \mathrm{IU} / \mathrm{ml}$ and anti-cyclic citrullinated peptide antibodies (Anti-CCP) was 38.3 \pm $65.5 \mathrm{U} / \mathrm{ml}$. and the mean number of joints affected was $3 \pm 1.8$ (rang between 2-8 joints).
Regarding the severity of RA, $18 \%$ of cases were in remission, $64 \%$ lower severity and $18 \%$ had moderate Severity. The mean disease activity score DAS28-ESR was (3.02 .72) ranged from (1.1-4.9).

DAS-28 positively correlated with a significance with ESR $(r=0.78 \& p=0.0001)$, CRP $(r=$ $0.387 \& p=0.007), \operatorname{RF}(r=0.59 \& p=0.0001)$, Anti$\mathrm{CCP}(r=0.72 \& p=0.0001)$, number of joints affected $(r=0.78 \& p=0.0001)$, flow $(r=0.78 \& p=0.001)$, number of joints affected $(r=0.78 \& p=0.0001)$ and number of joints swollen $(r=0.85 \& p=0.0001)$. DAS-28 did not correlate with age $(r=0.024 \&$ $p=0.867$ ).

There was a statistically significant link between RA and CX3CR1 ( $p=0.0001)$ as; AA constituted the highest percentage in cases vs. controls $(28 \%$ vs. $20 \%)$, AG was detected in 21 cases (42\%) while not detected in controls $(0 \%)$ and GG was detected in 15 cases $(30 \%)$ vs. 20 controls $(80 \%)$.

There was a statistically significant difference between cases vs controls as regard to the flowcytometry Fig. (1) as the median of flowcytometry in cases was significantly higher than the median flowcytometry of control [4.8 (2.8-22.7) vs. 1.26 (0.61-2.18) respectively] ( $\mathrm{U}=84, p=.0001)$.

There was a statistically significant positive correlation between flowcytometry and [ESR, CRP, Rheumatoid Factor (RF), Anti-CCP and number of joints affected] as $p$-value <.05. While, there was insignificant correlation between flowcytometry and the age (Table 3 ).

There was a statistically significant link between CX3CR1 among RA patients and number of joint affected as illustrated in Fig. (2).

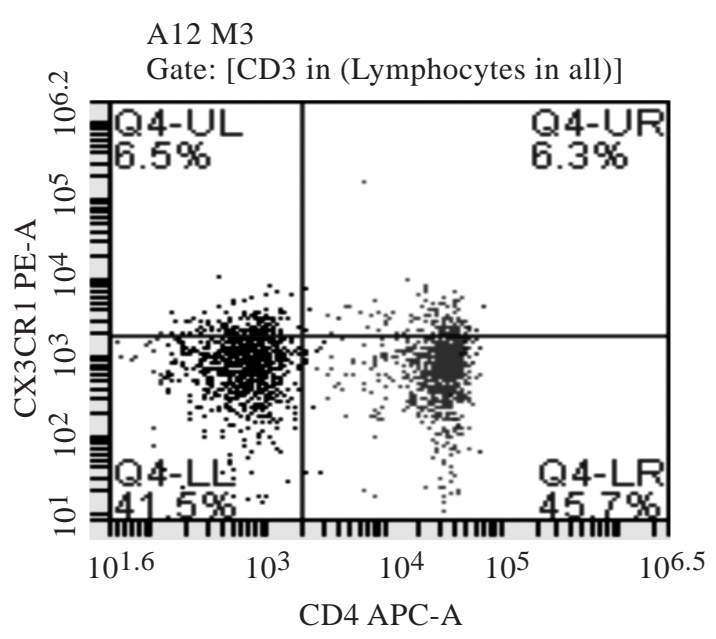

Fig. (1): Flowcytometry chart for CX3CR1. 


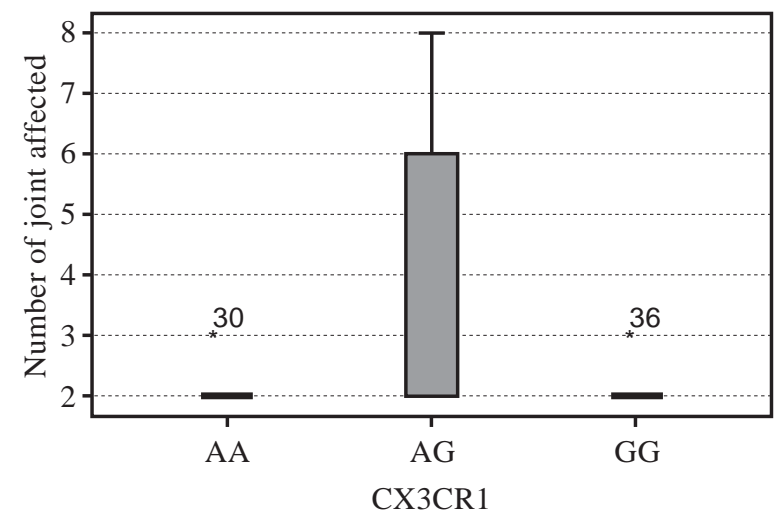

Fig. (2): Relations between Cx3cr1 among patients diagnosed with RA with number of joint affected.

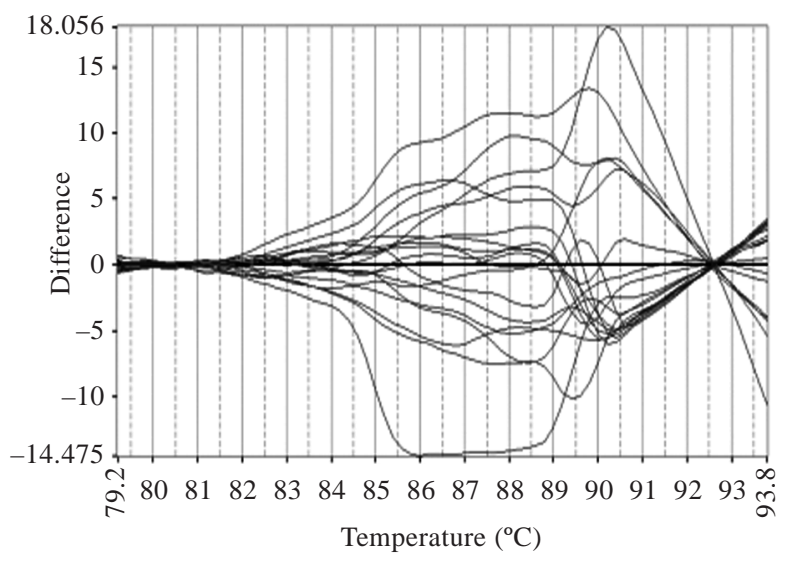

Fig. (4): CX3CR1 by HRM-RT of patient.

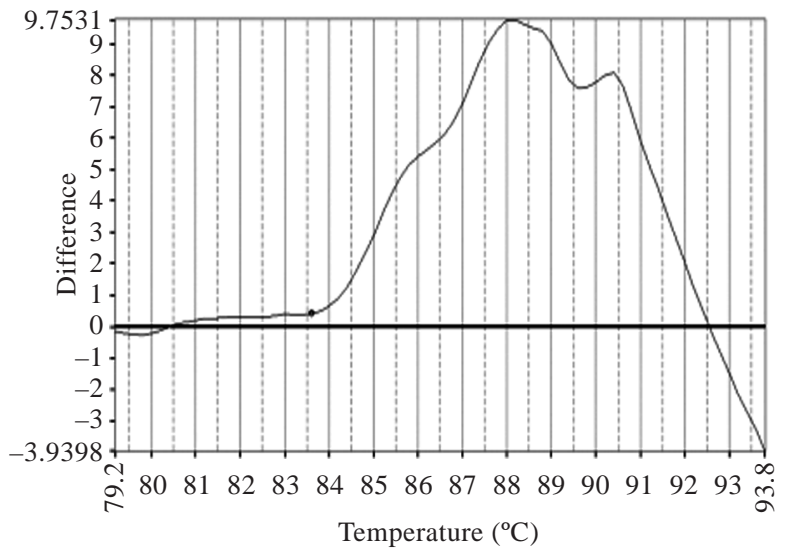

Fig. (6): Genotype AA.

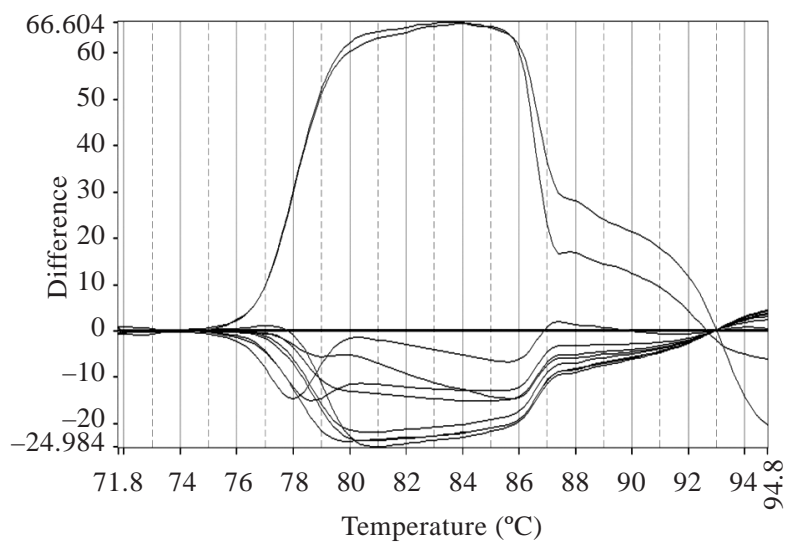

Fig. (3): CX3CR1 by HRM-RT of control.

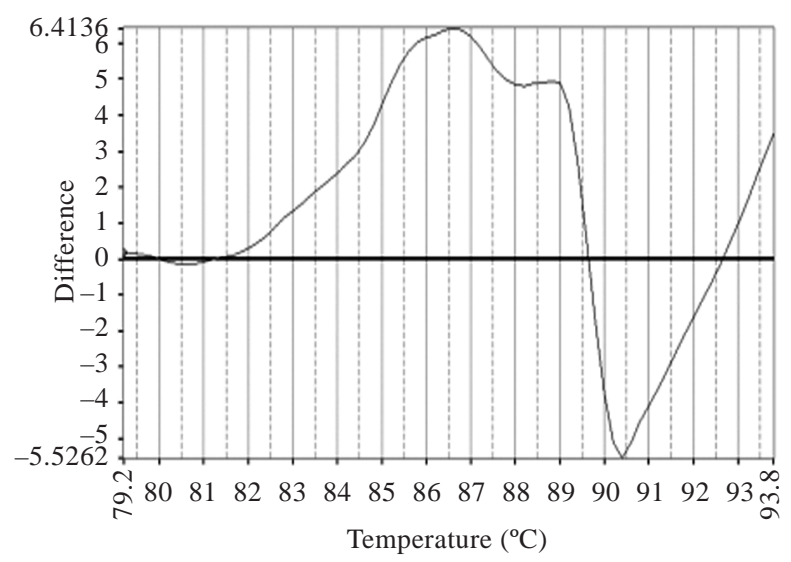

Fig. (5): Genotype AG.

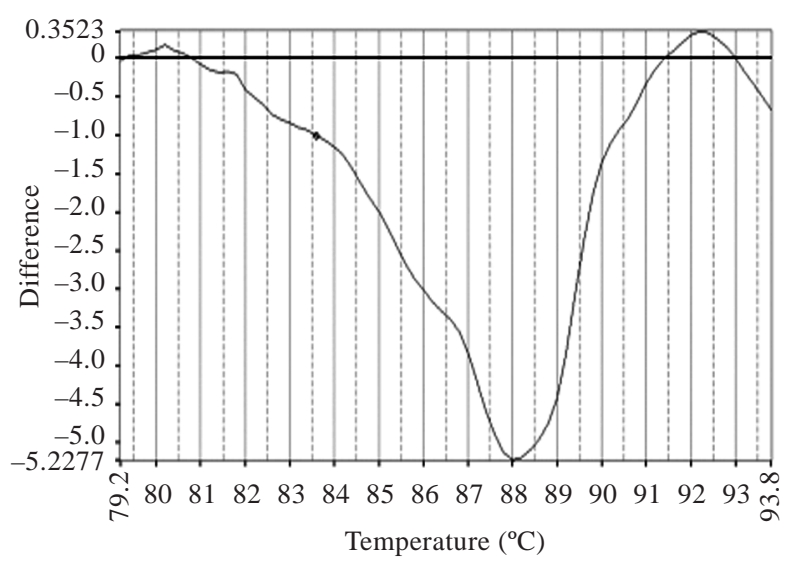

Fig. (7): Genotype GG.

Table (3): Correlation between flowcytometry among patients diagnosed with RA with some parameters.

\begin{tabular}{|c|c|c|c|c|c|c|c|}
\hline \multirow[b]{2}{*}{ Flow-cytometry (\%) } & \multirow{2}{*}{$\begin{array}{l}\text { Flow- } \\
\text { cytometry } \\
(\%)\end{array}$} & \multicolumn{6}{|c|}{ Some parameters } \\
\hline & & $\begin{array}{l}\text { Age } \\
\text { (Years) } \\
(\mathrm{N}=14)\end{array}$ & $\begin{array}{c}\text { ESR } \\
(\mathrm{mm} / \mathrm{hr}) \\
(\mathrm{N}=14)\end{array}$ & $\begin{array}{c}\text { CRP } \\
(\mathrm{mg} / \mathrm{dl}) \\
(\mathrm{N}=14)\end{array}$ & $\begin{array}{c}\mathrm{RF} \\
(\mathrm{IU} / \mathrm{ml}) \\
(\mathrm{N}=14)\end{array}$ & $\begin{array}{l}\text { Anti-CCP } \\
(\mathrm{U} / \mathrm{mL}) \\
(\mathrm{N}=14)\end{array}$ & $\begin{array}{c}\text { Number of } \\
\text { joints affected } \\
(\mathrm{N}=14)\end{array}$ \\
\hline $\begin{array}{l}r \\
p\end{array}$ & 1 & $\begin{array}{l}.074 \\
.801\end{array}$ & $\begin{array}{l}.77 \\
.001 *\end{array}$ & $\begin{array}{l}.77 \\
.001 *\end{array}$ & $\begin{array}{l}.67 \\
.009 *\end{array}$ & $\begin{array}{l}.78 \\
.001 *\end{array}$ & $\begin{array}{l}.8 \\
.001 *\end{array}$ \\
\hline $\begin{array}{l}* \quad \text { : Denote significa } \\
\text { RA : Rheumatoid Arth } \\
\text { ESR : Erythrocyte Sedi } \\
\text { CRP : C-Reactive Prote }\end{array}$ & s. & $\begin{array}{l}\text { RF } \\
\text { Anticcp } \\
\mathrm{N}\end{array}$ & $\begin{array}{l}\text { Rheumatoic } \\
\text { Anti-cyclic } \\
\text { Number. }\end{array}$ & $\begin{array}{l}\text { actor. } \\
\text { trullinated }\end{array}$ & ptide. & $\begin{array}{l}\mathrm{U} / \mathrm{ml}: \text { Unit } / \mathrm{m} \\
\mathrm{IU} / \mathrm{ml}: \text { Interna } \\
\mathrm{Hr} \quad: \text { Hour. }\end{array}$ & $\begin{array}{l}\text { liter. } \\
\text { onal unit/milliter. }\end{array}$ \\
\hline
\end{tabular}




\section{Discussion}

Rheumatoid arthritis is a chronic inflammatory autoimmune systemic disorder of the synovial membrane of the joints causing progressive destruction of the joint, chronic disability, premature death, socioeconomic adverse effects and poor quality of life due to the limitation of the daily activity. In order to develop a new therapy which could effectively cure all stages of the disease, the pathology of the disease should be crystal clear [7].

The small molecule therapeutics has been the focus of the 21 stcentury and this encouraged the emerging therapies which act via blocking the extracellular communication, interruption of the intracellular signaling through inhibition of kinases [8].

CX3CL1 is a membrane-bound chemokine expressed on cytotoxic effector lymphocytes, osteoclasts, monocytes and macrophages. It has a transmembrane domain and a chemokine/mucin hybrid structure and acts either as an adhesion molecule or as a chemoattractant [9].

Regarding the severity of RA in the current study, $18 \%$ of cases were in remission, $64 \%$ lower severity and $18 \%$ had moderate severity. The mean disease activity score-28 (DAS-28) was (3.02士.72) which ranged from (1.1-4.9). Similarly, Gamal et al., included 86 RA patients who demonstrated all grades of disease activity according to the DAS28 [10].

According to the study of Sato et al., the baseline DAS-28 was 5.9 [11]. Skogh et al., found the DAS-28 (mean $\pm \mathrm{SD}=4.04 \pm 1.48)$ [12]. A total of 111 patients were evaluated by Medeiros et al., who reported a mean \pm SD value of DAS-28 = $3.55 \pm 1.27$ and a median interquartile range of 25 75 [13]. Of the 249 patients enrolled in the study of Slimani et al., the mean DAS-28 at inclusion was 4.3 while atremission was $\leq 2.6$ [14].

This study demonstrated that DAS-28 positively correlated with a significance with ESR $(r=0.78$ $\& p=0.0001), \operatorname{CRP}(r=0.387 \& p=0.007), \operatorname{RF}(r=$ $0.59 \& p=0.0001)$, Anti-CCP $(r=0.72 \& p=0.0001)$, number of joints affected $(r=0.78 \& p=0.0001)$, flow ( $r=0.78 \& p=0.001)$, number of joints affected $(r=0.78 \& p=0.0001)$ and number of joints swollen $(r=0.85 \& p=0.0001)$. DAS-28 did not correlate with age $(r=0.024 \& p=0.867)$.

Similarly, according to McWilliams et al., DAS28 components positively correlated with the serum
CRP level while the weakest correlation of DAS28 was with the tender swollen ratio which against our results [15].

In contrast, Orr et al., performed their study on 223 cases of RA with knee arthralgia and reported that DAS-28 significantly positively correlated with the severity of the inflammatory reaction, yet the correlation was weak $(p=0.0011)[16]$.

In this study among the cases group, the mean value of ESR was $19.02 \pm 9.14 \mathrm{~mm} / \mathrm{hr}$, CRP was $3.86 \pm 1.27 \mathrm{mg} / \mathrm{dl}$, RF was $10.9 \pm 6.225 \mathrm{IU} / \mathrm{ml}$ and Anti-CCP was $38.3 \pm 65.5 \mathrm{U} / \mathrm{ml}$. with mean number of joints affected was $3 \pm 1.8$ (rang between 2-8 joints). In harmony with our study, Navarro-Millán et al., found that the mean CRP, ESR, levels were $1.8 \pm 3.0 \mathrm{mg} / \mathrm{dL}, 30.0 \pm 26.1 \mathrm{~mm} / \mathrm{h}$ respectively; $69 \%$ of patients with RA were seropositive [17]. In Skogh et al., study they investigated 70 patients with RA. The CRP mean \pm SD value of $15.65 \pm 19.16$ and ranged from 5 to $122 \mathrm{mg} / \mathrm{l}$ while ESR was $25.4 \pm 2.73$ $\mathrm{mm} / 1^{\text {st }}$ hourand ranged from 2 to $105 \mathrm{~mm} / 1^{\text {st }}$ hour [12]. Also, Sakr et al., reported that the polyarticular pattern was the predominant pattern of joint involvement detected in $77.1 \%$ of the enrolled patients [18].

While Slimani et al., reported higher value as their ESR was $40.6 \pm 26.3$, CRP was $11.1 \pm 15$, the number of tender joint was $5.0 \pm 4.8$ and the number of the swollen joints was $2.0 \pm 2.9$ [14].

In contrast, Shen et al., reported a significantly different RF, Anti-CCP antibody, CRP, and ESR values between the RA cases and their controls ( $p$

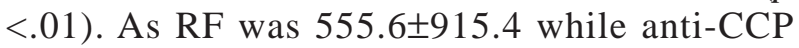
antibody was $68.9 \pm 79.9$, CRP was $44 \pm 56.6 \&$ ESR was $64.6 \pm 31.8$ which are much higher than our results and this may be explained by measurement during the activity. Also, we did not compare lab data of both groups [19].

In this study, there was a statistically significant difference between RA and control group regarding CX3CR1 $(p=0.001)$. AA constituted the highest percentage (28\% vs. $20 \%)$, AG ( $42 \%$ vs. $0 \%)$ and GG (30\% vs. $80 \%)$ in cases vs. controls respective1y. This observation is not surprising as CX3CR 1 participates tissue injuries and stimulates the infiltration of the sites of injury by immune cells [9].

Our results were confirmed by Sato et al., who found that the serum levels and expression of CX3CR1 in RA patients (4500 \pm 2179 units) were significantly higher than healthy individuals (194.7 \pm 114.0 units $)$ as $(p=0.01)$ [11]. 
Similarly, Chapman et al., analyzed fractalkine receptor (CX3CR1) expression by peripheral blood and synovial $\mathrm{T}$ cells and reported that CX3CR1 was upregulated in RA patients [20].

Also, Pingiotti et al., reported that that the peripheral blood isolated CX3CR1 were highly predominate in RA patients than the healthy controls [21].

Ruth et al., reported that the CX3CR1 could be detected in monocytes/macrophages, dendritic cells in RA synovium [22].

In our study, the expression of CX3CR 1 was significantly linked to the number of joints affected among RA patients which was considered as a reflection of the disease activity $(p=0.002)$. Pingiotti et al., \& Matsunawa et al., demonstrated an upregulated expression of CX3CR1 in RA with the highest level belonged to the more severe cases $[21,23]$. Similarly, Tarrant et al., found that the severity of the arthritis was 30\% less in the CX3CR1/mice than the wild-type mice, joint swelling $(p<0.01)$ and clinical disease score $(p<0.0001)$ were less severe as well [24].

On the other hand, according to the study of Aldahlawi et al., there was no significant difference in CX3CR1 cells according to RA activity (either active or non-active) [25].

There was a statistically significant difference between cases vs controls as regard to the flow as the median of flow in cases was significantly higher than the median flow of control $(4.8(2.8-22.7)$ vs. $1.26(0.61-2.18)$ respectively) $(\mathrm{U}=84, p=.0001)$.

Similarly, in functional studies investigating fractalkine mediated chemoattraction of monocytes as well as flowcytometric detection of a great percentage of CX3CR1 positive monocytes in RA peripheral blood and synovial fluid $[\mathbf{2 0 , 2 2 , 2 6 ]}$.

This was in line with the flowcytometric results of RA cases involved in the study of Ruth et al., which demonstrated that the disease activity significantly correlated with increased CX3CR 1 expression in the synovial fluid [22].

In contrast, Nanki et al., reported a very low expression of the surface CX3CR 1 expression in synovial cells of RA by flowcytometric studies [27].

According to the study in hands, the flowcytometric studies significantly, positively correlated with ESR $(r=0.77 \& p=.001)$, CRP $(r=0.77 \& p=$ $0.001), \operatorname{RF}(r=0.67 \& p=0.009)$, Anti-CCP $(r=0.78$
$\& p=0.001)$ and number of joints affected $(r=0.8$ $\& p=0.001)$. While insignificantly, positively correlated with the age $(p=0.801)$.

This was similar to the elevated CX3CR1 levels which correlated positively with C-reactive protein levels, and ESR which observed by Kasama et al., in their study [28].

Also, this was in disagreement with Aldahlawi et al., study in which CX3CR1 was analyzed using the flowcytometry, they showed that, it significantly negatively correlated with ESR, CRP, RF and AntiCCP [25].

Major limitations of our study are its design as a single center study, the relatively small sample size, the absent screening of a complete panel of auto-antibodies, the use of the 1987 ACR diagnostic criteria for RA instead of the updated 2010 ACR/ EULAR criteria which was intended as the study included cases diagnosed since 1995 and compared them to previously published studies which also adopted the same diagnostic criteria. Also, the course of the disease is more likely to be affected by many concomitant factors rather than the risk factors. For instance, the variable diet, physical activity and body weight of the patients which might infleunce the CX3CR1 expression.

As the avalible few studies are insufficient for a full understanding of the role of CX3CR1 in the RA pathogensis, larger detailed studies are required to clear the exact pathology of RA. More larger multicenter study with central imaging review ona larger sample is required. This study could be thestarting point and base of multicenterbased study.

\section{Conclusion:}

Our results confirmed the CX3CR 1 is a valuable biomarker of RA activity with a significant role in the local joint RA-induced inflammatory reaction without affecting the systemic immune system. These results give rise to the therapeutic potentials of targeting the CX3CR1 pathway.

\section{Conflict of interest:}

No conflict of interest.

\section{References}

1- HOVDENES J.: B-cell growth-promoting activity in supernatants from CD4+ cells from synovial fluid and peripheral blood of patients with rheumatoid arthritis and other inflammatory arthritides, Scandinavian Journal of Rheumatology, 18: 385-92, 1989.

2- SZEKANECZ Z., VEGVARI A., SZABO Z. and KOCH A.E.: Chemokines and chemokine receptors in ar- 
thritis, Frontiers in bioscience (Scholar edition), 2: 15367, 2010.

3- NANKI T., IMAI T. and KAWAI S.: Fractalkine/CX3CL1 in rheumatoid arthritis, Modern Rheumatology, 27: 3927, 2017.

4- TARRANT T.K., LIU P., RAMPERSAD R.R., ESSERMAN D., ROTHLEIN L.R., TIMOSHCHENKO R.G., et al.: Decreased Th17 and antigen-specific humoral responses in CX3CR1-deficient mice in the collagen-induced arthritis model, Arthritis \& Rheumatism, 64: 1379-87, 2012.

5- MULLER G., HOPKEN U.E., STEIN H. and LIPP M.: Systemic immunoregulatory and pathogenic functions of homeostatic chemokine receptors, Journal of Leukocyte Biology, 72: 1-8, 2002.

6- GULLICK N.J., ABOZAID H.S., JAYARAJ D.M., EVANS H., SCOTT D., CHOY E., et al.: Enhanced and persistent levels of interleukin (IL)-17+ CD 4+ T cells and serum IL-17 in patients with early inflammatory arthritis, Clinical \& Experimental Immunology, 174: 292-301, 2013.

7- GUO Q., WANG Y., XU D., NOSSENT J., PAVLOS N.J. and XU J.: Rheumatoid arthritis: Pathological mechanisms and modern pharmacologic therapies, Bone Research, 6: $15,2018$.

8- KELLY V. and GENOVESE M.: Novel small molecule therapeutics in rheumatoid arthritis, Rheumatology, 52: 1155-62, 2013.

9- IMAI T. and YASUDA N.: Therapeutic intervention of inflammatory/immune diseases by inhibition of the fractalkine (CX3CL1)-CX3CR1 pathway, Inflammation and Regeneration, 36: 9, 2016.

10- GAMAL R.M., MAHRAN S.A., ABO EL FETOH N. and JANBI F.: Quality of life assessment in Egyptian rheumatoid arthritis patients: Relation to clinical features and disease activity, The Egyptian Rheumatologist, 38: 65-70, 2016.

11- SATO M., OHTSUKA K., TAKAHASHI R., WAKABAYASHI K., ODAI T., ISOZAKI T., et al.: Involvement of CX3CL1/CX3CR1 axis in etanercept therapy for patients with active rheumatoid arthritis, Open access rheumatology: Research and Reviews, 3: 1-7, 2011.

12- SKOGH T., GUSTAFSSON D., KJELLBERG M. and HUSBERG M.: Twenty eight joint count disease activity score in recent onset rheumatoid arthritis using $\mathrm{C}$ reactive protein instead of erythrocyte sedimentation rate, Annals of the Rheumatic Diseases, 62: 681-2, 2003.

13- MEDEIROS M.M.D.C., OLIVEIRA B.M.G.B.D., CERQUEIRA J.V.M.D., QUIXADA R.T.D.S. and OLIVEIRA Í.M.A.X.D.: Correlation of rheumatoid arthritis activity indexes (Disease Activity Score 28 measured with ESR and CRP, Simplified Disease Activity Index and Clinical Disease Activity Index) and agreement of disease activity states with various cut-off points in a Northeastern Brazilian population, Revista Brasileira de Reumatologia (English Edition), 55: 477-84, 2015.

14- SLIMANI S., ABBAS A., AMMAR A.B., KEBAILI D., RAHAL F., KHAMARI M.C., et al.: Characteristics of rheumatoid arthritis in Algeria: A multicenter study, Rheumatology International, 34: 1235-9, 2014.
15- MCWILLIAMS D.F., KIELY P.D., YOUNG A., JOHARATNAM N., WILSON D. and WALSH D.A.: Interpretation of DAS28 and its components in the assessment of inflammatory and non-inflammatory aspects of rheumatoid arthritis, BMC Rheumatology, 2: 8, 2018.

16- ORR C.K., NAJM A., YOUNG F., MCGARRY T., BINIECKA M., FEARON U., et al.: The Utility and Limitations of CRP, ESR and DAS28-CRP in Appraising Disease Activity in Rheumatoid Arthritis, Front Med. (Lausanne), 5: 185, 2018.

17- NAVARRO-MILLAN I., YANG S., DUVALL S.L., CHEN L., BADDLEY J., CANNON G.W., et al.: Association of hyperlipidaemia, inflammation and serological status and coronary heart disease among patients with rheumatoid arthritis: Data from the National Veterans Health Administration, Annals of the Rheumatic Diseases, 75: 341-7, 2016.

18- SAKR B.R., ELFISHAWI M.M., ELAROUSY M.H., HATW A.K., ABDULKARIM A.N., TAMMAM A.B., et al.: Rheumatoid arthritis: A single-center Egyptian experience, Immunological Investigations, 47: 293-302, 2018.

19- SHEN R., REN X., JING R., SHEN X., CHEN J., JU S., et al.: Rheumatoid Factor, Anti-Cyclic Citrullinated Peptide Antibody, C-Reactive Protein, and Erythrocyte Sedimentation Rate for the Clinical Diagnosis of Rheumatoid Arthritis, Laboratory Medicine, 46: 226-9, 2015.

20- CHAPMAN G.A., MOORES K.E., GOHIL J., BERKHOUT T.A., PATEL L., GREEN P., et al.: The role of fractalkine in the recruitment of monocytes to the endothelium, European Journal of Pharmacology, 392: 189-95, 2000.

21- PINGIOTTI E., CIPRIANI P., MARRELLI A., LIAKOULI V., FRATINI S., PENCO M., et al.: Surface expression of fractalkine receptor (CX3CR1) on CD4+/CD28-T cells in RA patients and correlation with atherosclerotic damage, Annals of the New York Academy of Sciences, 1107: 3241, 2007.

22- RUTH J.H., VOLIN M.V., HAINES III G.K., WOODRUFF D.C., KATSCHKE Jr K.J., WOODS J.M., et al.: Fractalkine, a novel chemokine in rheumatoid arthritis and in rat adjuvant-induced arthritis, Arthritis \& Rheumatism: Official Journal of the American College of Rheumatology, 44: 1568-81, 2001.

23- MATSUNAWA M., ISOZAKI T., ODAI T., YAJIMA N., TAKEUCHI H.T., NEGISHI M., et al.: Increased serum levels of soluble fractalkine (CX3CL1) correlate with disease activity in rheumatoid vasculitis, Arthritis \& Rheumatism: Official Journal of the American College of Rheumatology, 54: 3408-16, 2006.

24- TARRANT T.K., LIU P., RAMPERSAD R.R., ESSERMAN D., ROTHLEIN L.R., TIMOSHCHENKO R.G., et al.: Decreased Th17 and antigen-specific humoral responses in $\mathrm{CX}_{3}$ CR1-deficient mice in the collagen-induced arthritis model, Arthritis and Rheumatism, 64: 1379-87, 2012.

25- ALDALAWI A.M., ELSHAL M.F., ASHGA F.T. and BAHLAS S.: Chemokine receptors expression on peripheral CD4-lymphocytes in rheumatoid arthritis: Coexpression of CCR7 and CD95 is associated with disease activity, Saudi Journal of Biological Sciences, 22: 453-8, 2015. 
26- BAZAN J.F., BACON K.B., HARDIMAN G., WANG W., SOO K., ROSSI D., et al.: A new class of membranebound chemokine with a CX3C motif, Nature, 385: 6404, 1997.

27- NANKI T., IMAI T., NAGASAKA K., URASAKI Y., NONOMURA Y., TANIGUCHI K., et al.: Migration of CX3CR1-positive $\mathrm{T}$ cells producing type 1 cytokines and cytotoxic molecules into the synovium of patients with rheumatoid arthritis, Arthritis \& Rheumatism, 46: 287883, 2002.

28- KASAMA T., WAKABAYASHI K., SATO M., TAKAHASHI R. and ISOZAKI T.: Relevance of the CX3CL1/ fractalkine-CX3CR1 pathway in vasculitis and vasculopathy, Translational Research, 155: 20-6, 2010.

\section{دراسلة جينية لجزئ فى مرضى إلتهاب المفاصل الروماتويلىى}

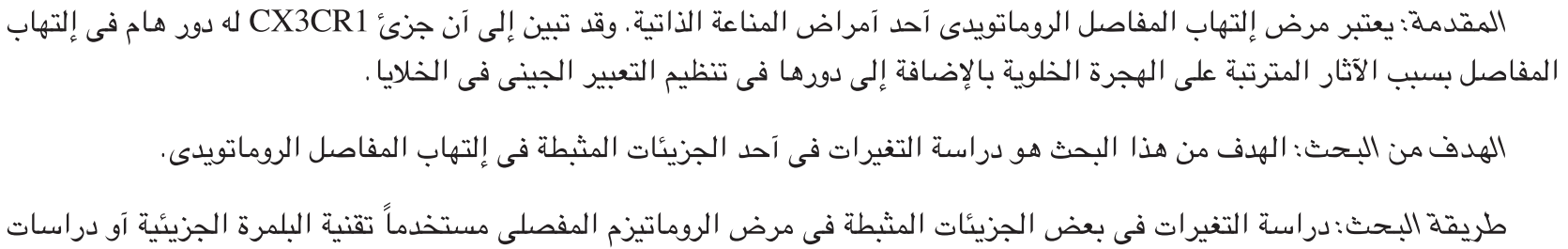

